\title{
Interactive comment on "Improved
}

1-km-resolution $\mathrm{PM}_{2.5}$ estimates across China using the space-time extremely randomized trees" by Jing Wei et al.

\section{Anonymous Referee \#1}

Received and published: 6 November 2019

Please see the attached pdf file for comments.

Please also note the supplement to this comment: https://www.atmos-chem-phys-discuss.net/acp-2019-815/acp-2019-815-RC2supplement.pdf

Interactive comment on Atmos. Chem. Phys. Discuss., https://doi.org/10.5194/acp-2019-815, 2019. 